\title{
Relationship Between Blockade of Dopamine Transporters by Oral Methylphenidate and the Increases in Extracellular Dopamine: Therapeutic Implications
}

\author{
NORA D. VOLKOW, ${ }^{1,2 *}$ GENE-JACK WANG, ${ }^{1}$ JOANNA S. FOWLER, ${ }^{1}$ JEAN LOGAN, ${ }^{1}$ \\ DINKO FRANCESCHI, ${ }^{1}$ LAURENCE MAYNARD, ${ }^{1}$ YU-SHIN DING, ${ }^{1}$ SAMUEL J. GATLEY, ${ }^{1}$ \\ ANDREW GIFFORD, ${ }^{1}$ WEI ZHU, ${ }^{3}$ AND JAMES M. SWANSON ${ }^{4}$ \\ ${ }^{1}$ Brookhaven National Laboratory, Upton, New York 11973 \\ ${ }^{2}$ Department of Psychiatry, State University of New York at Stony Brook, Stony Brook, New York 11794 \\ ${ }^{3}$ Department of Applied Mathematics, State University of New York at Stony Brook, Stony Brook, New York 11794 \\ ${ }^{4}$ University of California at Irvine, Child Development Center, Irvine, California 92612
}

\begin{abstract}
KEY WORDS attention deficit hyperactivity disorder; imaging; Ritalin; raclopride; DA receptors; striatum
\end{abstract}

\begin{abstract}
Methylphenidate (Ritalin) is an effective drug in the treatment of attention deficit hyperactivity disorder. However, the doses required therapeutically vary significantly between subjects and it is not understood what determines these differences. Since methylphenidate's therapeutic effects are in part due to increases in extracellular DA secondary to blockade of dopamine transporters (DAT), the variability could reflect differences in levels of DAT blockade. Here we used PET to assess if for a given dose of methylphenidate the differences in DAT blockade account for the variability in methylphenidate-induced increases in extracellular DA. Ten healthy adult subjects were tested before and $60 \mathrm{~min}$ after oral methylphenidate $(60 \mathrm{mg})$ with PET to estimate DAT occupancy (with $\left[{ }^{11} \mathrm{C}\right]$ cocaine as the radioligand) and levels of extracellular DA (with $\left.{ }^{11} \mathrm{C}\right]$ raclopride as the D2 receptor radioligand that competes with endogenous DA for binding to the receptor). Methylphenidate significantly blocked DAT (60 \pm $11 \%)$ and increased extracellular DA in brain $\left(16 \pm 8 \%\right.$ reduction in $\left[{ }^{11} \mathrm{C}\right]$ raclopride binding in striatum). However, the correlation between methylphenidate-induced DAT blockade and DA increases was not significant. These results indicate that for a given dose of methylphenidate, individual differences in DAT blockade are not the main source for the intersubject variability in MP-induced increases in DA. This finding suggests that individual differences in response to MP are due in part to individual differences in DA release, so that for an equivalent level of DAT blockade, MP would induce smaller DA changes in subjects with low than with high DA cell activity. Synapse 43:181-187, 2002. ๑ 2002 Wiley-Liss, Inc.
\end{abstract}

\section{INTRODUCTION}

Attention deficit hyperactivity disorder (ADHD) is the most common behavioral disorder of childhood; its prevalence is estimated to be $5-10 \%$ of the general population (Swanson et al., 1998). An increase in recognition of ADHD over the past decade has led to a dramatic increase in the prescription of methylphenidate (MP), the drug of choice in the treatment of ADHD (Swanson et al., 1995). MP is very effective for the treatment of $\mathrm{ADHD}$; it is estimated that $60-70 \%$ of ADHD subjects have favorable responses. The doses required to achieve clinical responses vary significantly across individuals ( 0.1 to $1 \mathrm{mg} / \mathrm{kg}$ ) (Swanson et al., 1991). The mechanisms underlying this variability are not understood.
This research was carried out at Brookhaven National Laboratory (BNL). Contract grant sponsor: U.S. Department of Energy OBER; Contract grant number: DE-ACO2, 98CH10886. Contract grant sponsor: the National Institute on Drug Abuse; Contract grant number: DA09490-01, and DA06278.

*Correspondence to: Nora Volkow, M.D., Brookhaven National Laboratory, Upton, NY 11973. E-mail: volkow@bnl.gov

Received 8 August 2001; Accepted 23 October 2001 
MP's therapeutic effects are believed to rely on its ability to block the dopamine (DA) and the norepinephrine transporters (Solanto, 1998). Particularly relevant are its effects on DA transporters (DAT) in view of the recent findings documenting significant increases in DAT in subjects with ADHD (Dougherty et al., 1999; Krause et al., 2000) and the reported association between expression of the DAT1 allele and scores of hyperactivity-impulsivity in subjects with ADHD (Waldman et al., 1998). We have developed and used methods based on positron emission tomography (PET) with different radiotracers to image, in adult volunteers, the effects of oral doses of MP on brain DA activity. In our prior work with MP, we documented that in the human brain clinical doses of MP significantly block DAT (>50\%) (Volkow et al., 1998). In separate studies, we documented that oral doses of MP also increase extracellular DA (Volkow et al., 2001), which we hypothesized was the next step in the process by which this drug produces an agonist effect. Based on this model, here we use PET to address the hypothesis that individual differences in DAT blockade are related to individual differences in MP-induced increases in extracellular DA.

PET was used with $\left[{ }^{11} \mathrm{C}\right]$ cocaine, a DAT ligand (Fowler et al., 1989), to measure the levels of DAT blockade by MP and with $\left[{ }^{11} \mathrm{C}\right]$ raclopride, a DA D2 receptor radioligand sensitive to competition with DA, to measure MP-induced changes in extracellular DA (Volkow et al., 1994). Because $\left[{ }^{11} \mathrm{C}\right]$ raclopride binding is highly reproducible (Volkow et al., 1993), differences in binding between placebo and MP predominantly reflect drug-induced changes in extracellular DA (Dewey et al., 1993). Both the measures of druginduced DAT blockade with $\left[{ }^{11} \mathrm{C}\right]$ cocaine (Volkow et al., 1997a), and of DA changes with $\left[{ }^{11} \mathrm{C}\right]$ raclopride are reproducible when subjects are tested on different days (Wang et al., 1999). The findings of MP effects on the $\left[{ }^{11} \mathrm{C}\right]$ raclopride binding for some of the subjects were previously published as part of a study that assessed the effects of MP on extracellular DA (Volkow et al., 2001).

\section{MATERIALS AND METHODS Subjects}

Participants were 10 male healthy subjects (age $33 \pm$ $8 \mathrm{SD}$ years; weight $164 \pm 28 \mathrm{lb}$ ) who did not have a present or past history of drug or alcohol abuse or dependence (excluding nicotine/caffeine) as defined by DSM IV criteria. Subjects were excluded if they had a current or past psychiatric, neurological, cardiovascular, or endocrinological disease. None of the subjects was taking medications at the time of the study. Toxicological drug screens were performed prior to each PET scan. Studies were approved by the Institutional Review Board at Brookhaven National Laboratory and informed consent was obtained from all subjects after procedures were explained.

\section{Scans}

Subjects had two scans with $\left[{ }^{11} \mathrm{C}\right]$ cocaine done in 1 day and two scans with $\left[{ }^{11} \mathrm{C}\right]$ raclopride on a different day. The first scan on a given day was done $60 \mathrm{~min}$ after placebo (saline tablet) and the second scan was done $60 \mathrm{~min}$ after $60 \mathrm{mg}$ of oral MP $(0.81 \pm 15 \mathrm{mg} / \mathrm{kg})$. The scans were performed $2 \mathrm{~h}$ apart from each other and the subjects were blind to whether placebo or oral MP was administered. The order of the radiotracers was randomly varied. Scans were done using a CTI 931 tomograph $(6 \times 6 \times 6.5 \mathrm{~mm}$ full-width half-maximum $)$ after i.v. injection of $4-8 \mathrm{mCi}$ of $\left[{ }^{11} \mathrm{C}\right]$ cocaine (specific activity $>0.2 \mathrm{Ci} / \mu \mathrm{mol}$ at time of injection) and after injection of $4-10 \mathrm{mCi}$ of $\left[{ }^{11} \mathrm{C}\right]$-raclopride (specific activity $0.5-1.5 \mathrm{Ci} / \mu \mathrm{M}$ at end of bombardment; $2-24 \mu \mathrm{g}$ injected dose). Scanning was started immediately after radiotracer injection for a series of 20 emission scans obtained through $60 \mathrm{~min}$; following procedures previously published for $\left[{ }^{11} \mathrm{C}\right]$ cocaine (Fowler et al., 1989) and for $\left[{ }^{11} \mathrm{C}\right]$ raclopride (Volkow et al., 1993). Arterial plasma samples were obtained throughout the procedures to quantify plasma concentration of ${ }^{11} \mathrm{C}$ and of nonmetabolized $\left[{ }^{11} \mathrm{C}\right]$ cocaine and $\left[{ }^{11} \mathrm{C}\right]$ raclopride as described (Fowler et al., 1989; Volkow et al., 1993).

\section{Drug effect ratings}

Behavioral effects were evaluated using analog scales that assessed self-reports of high, alertness, anxiety, restlessness, and drug effects from 1 (felt nothing) to 10 (felt intensely) (Wang et al., 1997) recorded $5 \mathrm{~min}$ before placebo or MP and then every 5 min for a total of $120 \mathrm{~min}$. Recordings for heart rate and blood pressure were obtained continuously throughout the placebo and MP scans.

\section{Image analysis and modeling}

Regions of interest (ROI) were outlined for striatum (ST) and cerebellum (CB) as described in prior studies (Volkow et al., 1993). The time-activity curves for the concentration of radiotracer in striatum and in cerebellum obtained from the dynamic PET scans and the time-activity curves for the concentration of radiotracer in arterial blood corrected for metabolites were used to obtain $\mathrm{K}_{1}$ (plasma to tissue transport constant) and the distribution volume (DV) using a graphical analysis technique for reversible systems (Logan et al., 1990). The ratio of DV in striatum to that in cerebellum, which corresponds to $(\mathrm{Bmax} / \mathrm{Kd})+1$ and is insensitive to changes in cerebral blood flow was used as model parameter to quantify DAT availability from the $\left[{ }^{11} \mathrm{C}\right]$ cocaine images (Logan et al., 1997) and DA D2 receptor availability from the $\left[{ }^{11} \mathrm{C}\right]$ raclopride images (Logan et al., 1994). The response to MP was quantified 
TABLE I. Estimates for $K_{1}$ and distribution volumes (DV) for $\left[{ }^{11} \mathrm{C}\right]$ cocaine and for $\left[{ }^{11} \mathrm{C}\right]$ raclopride after placebo and after methylphenidate (MP)

\begin{tabular}{lccccc}
\hline & \multicolumn{2}{c}{$\left[{ }^{11} \mathrm{C}\right]$ Cocaine } & & \multicolumn{2}{c}{$\left[{ }^{11} \mathrm{C}\right]$ Raclopride } \\
\cline { 2 - 3 } \cline { 5 - 6 } $\mathrm{K}_{1}$ & Placebo & $\mathrm{MP}$ & & Placebo & $\mathrm{MP}$ \\
\hline Cerebellum & $0.27 \pm 0.05$ & $0.26 \pm 0.06$ & & $0.06 \pm 0.01$ & $0.06 \pm 0.01$ \\
Striatum & $0.38 \pm 0.07$ & $0.35 \pm 0.10$ & & $0.09 \pm 0.01$ & $0.09 \pm 0.01$ \\
DV (ml/g) & & & & \\
Cerebellum & $2.11 \pm 0.47$ & $2.01 \pm 0.48$ & & $0.38 \pm 0.04$ & $0.36 \pm 0.04$ \\
Striatum & $4.22 \pm 1.07$ & $2.83 \pm 0.83^{*}$ & & $1.80 \pm 0.29$ & $1.46 \pm 0.20^{*}$ \\
\hline
\end{tabular}

Values correspond to means and standard deviations. *Differences between placebo and MP; paired $t$-tests, $P<0.005$.

as the difference in Bmax/Kd between placebo and MP and expressed as percent change from placebo.

\section{Data analysis}

Differences in $\mathrm{K}_{1}$, DV, Bmax/Kd for $\left[{ }^{11} \mathrm{C}\right]$ cocaine and for $\left[{ }^{11} \mathrm{C}\right]$ raclopride and in the behavioral (peak effects) and cardiovascular measures (averaged scores between 60-90 $\mathrm{min}$ ) between placebo and MP were tested with paired $t$-tests. To test for differences in the variability between MP-induced DAT blockade and MP-induced DA changes we compared the coefficient of variations (CV) between these two measures using the Jackknife resampling method (Efron, 1982) to create a sample of 10 pairs of "pseudo-values" for CV. A paired $t$-test was used to test the differences on these "pseudo-values" after testing for normality. Pearson product moment correlation analyses were calculated between MPinduced DAT blockade and the changes in DA and between age and DAT availability, MP-induced DAT blockade, and MP-induced DA changes.

\section{RESULTS}

MP did not affect the transport of $\left[{ }^{11} \mathrm{C}\right]$ cocaine or of $\left[{ }^{11} \mathrm{C}\right]$ raclopride from blood to brain $\left(\mathrm{K}_{1}\right)$ in striatum or in cerebellum nor did it affect their distribution volumes (DV) in cerebellum (Table I). In contrast, MP significantly reduced the DV of $\left[{ }^{11} \mathrm{C}\right]$ cocaine and of $\left.{ }^{[11} \mathrm{C}\right]$ raclopride in striatum (Table I). Figure 1 shows representative DV images for $\left[{ }^{11} \mathrm{C}\right]$ cocaine and for $\left[{ }^{11} \mathrm{C}\right]$ raclopride at the level of striatum obtained after placebo and after MP.

MP significantly reduced the estimates of DAT availability $(\mathrm{Bmax} / \mathrm{Kd})$ in striatum by $60 \pm 11 \%(t=18$, df $9, P<0.0001)$ and it decreased DA D2 receptor availability by $16 \pm 8 \%(t=5.7$, df $9, P<0.0003)$. The levels of DAT blockade ranged between $41 \%$ and $72 \%$ and the range of DA changes ranged between $3 \%$ and $27 \%$. The CV was significantly larger for DA changes $(50 \%)$ than for DAT blockade $(18 \%)(t=2$, df $9, P<0.05)$.

The correlation between MP-induced levels of DAT blockade and MP-induced changes in DA $(r=0.01$, df $9, P=0.98$ ) was not significant (Fig. 2A). In fact, there were subjects in whom MP induced significant DAT blockade $(>50 \%)$ but for whom MP did not in-

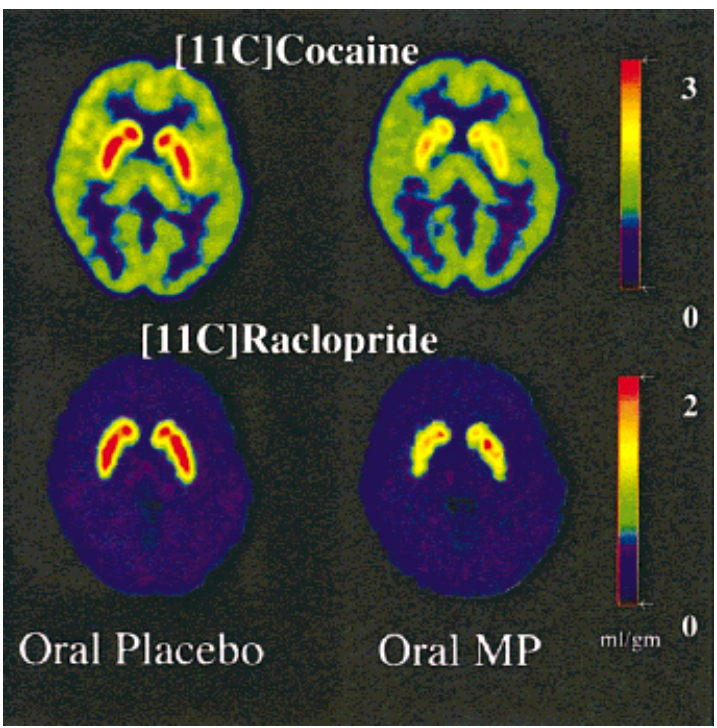

Fig. 1. Distribution volume images of $\left[{ }^{11} \mathrm{C}\right]$ cocaine and of $\left[{ }^{11} \mathrm{C}\right] \mathrm{ra}-$ clopride at the level of the striatum for one of the subjects at baseline and after administration of $60 \mathrm{mg}$ of oral methylphenidate (MP). MP reduced binding of $\left[{ }^{11} \mathrm{C}\right]$ cocaine and of $\left[{ }^{11} \mathrm{C}\right]$ raclopride in the striatum reflecting the occupancy of the DAT and the increases in extracellular DA and occupancy of DA D2 receptors by MP, respectively.
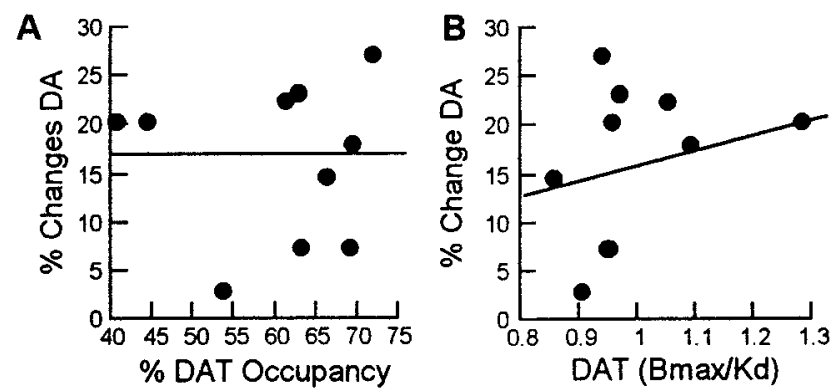

Fig. 2. A. Regression between MP-induced DAT blockade (assessed by percent change in $\left[{ }^{11} \mathrm{C}\right]$ cocaine's $\mathrm{Bmax} / \mathrm{Kd}$ ) and MP-induced changes in DA (assessed by percent change in $\left[{ }^{11} \mathrm{C}\right]$ raclopride's Bmax/ Kd) in striatum. B. Regression between baseline levels of DAT and MP-induced changes in DA in striatum.

crease extracellular DA. An inspection of the regression slope revealed two subjects that appeared as outliers. To assess if the lack of a correlation was due to these two subjects we calculated the correlation without them (even though they did not differ in their demographics or their behavioral and cardiovascular responses to MP from the others) and it was still nonsignificant ( $r=0.48$, df 7, $P=0.22$ ). Because we were also interested in assessing whether the baseline levels of DAT contributed to the variability in the response to MP we measured the correlation between DAT levels at baseline and MP-induced changes in DA; this correlation was not significant $(r=0.34$, df $9, P=0.33)$ (Fig. 2B).

The correlation with age of the subjects was significant for MP-induced DA changes $(r=0.72$, df $9, P<$ 0.02 ) and there was a trend for DAT availability at 
baseline ( $r=0.61$, df $9, P<0.06)$, but the correlation with MP-induced DAT blockade was not significant ( $r$ $=0.03, P=0.93$ ).

The behavioral effects of MP were significant $(P<$ 0.05 ) for self-reports of "high," "feel drug," and "restlessness" for the $\left[{ }^{11} \mathrm{C}\right]$ raclopride evaluation and though they were also increased for the $\left[{ }^{11} \mathrm{C}\right]$ cocaine evaluation (except for restlessness) the increases were not significant (Table II). However, comparison of the behavioral effects of MP between both evaluations showed no significant differences. The correlations between subject's age and the behavioral effects of MP were not significant (data not shown).

MP cardiovascular effects did not differ between the two evaluations (Fig. 3) and the MP effects were significant $(P<0.001)$ for increases in heart rate, which were similar for the $\left[{ }^{11} \mathrm{C}\right]$ cocaine evaluation to $16 \pm$ $10 \%$ and for the $\left[{ }^{11} \mathrm{C}\right]$ raclopride evaluation to $13 \pm 9 \%$. MP's effects on systolic and diastolic blood pressure were not significant.

In the subject in whom we had plasma measures of MP for the two evaluations, concentration of d-threo-

TABLE II. Behavioral effects of MP for the $\left[{ }^{11} \mathrm{C}\right]$ cocaine and the $\left[{ }^{11} \mathrm{C}\right]$ raclopride evaluations

\begin{tabular}{lccccc}
\hline & \multicolumn{2}{c}{$\left[{ }^{11} \mathrm{C}\right]$ Cocaine } & & \multicolumn{2}{c}{$\left[{ }^{11} \mathrm{C}\right]$ Raclopride } \\
\cline { 2 - 3 } & Placebo & MP & & Placebo & MP \\
\hline High & $2.0 \pm 1.7$ & $3.5 \pm 3.9$ & & $1.8 \pm 1.8$ & $4.6 \pm 3.6^{*}$ \\
Anxiety & $2.0 \pm 1.3$ & $2.7 \pm 2.2$ & & $2.3 \pm 2.8$ & $2.9 \pm 2.9$ \\
Restlessness & $1.9 \pm 1.3$ & $2.0 \pm 1.5$ & & $1.2 \pm 0.6$ & $3.1 \pm 2.9^{*}$ \\
Drug effect & $2.0 \pm 1.7$ & $3.8 \pm 3.9$ & & $1.8 \pm 1.8$ & $4.5 \pm 3.7^{*}$ \\
Alert & $8.2 \pm 2.5$ & $9.3 \pm 1.5$ & & $8.3 \pm 2.3$ & $8.8 \pm 1.7$ \\
\hline
\end{tabular}

*Significant differences between MP and placebo; paired $t$-tests, $P<0.05$.

None of the behavioral effects differed significantly between the two evaluations $(P<0.05)$.
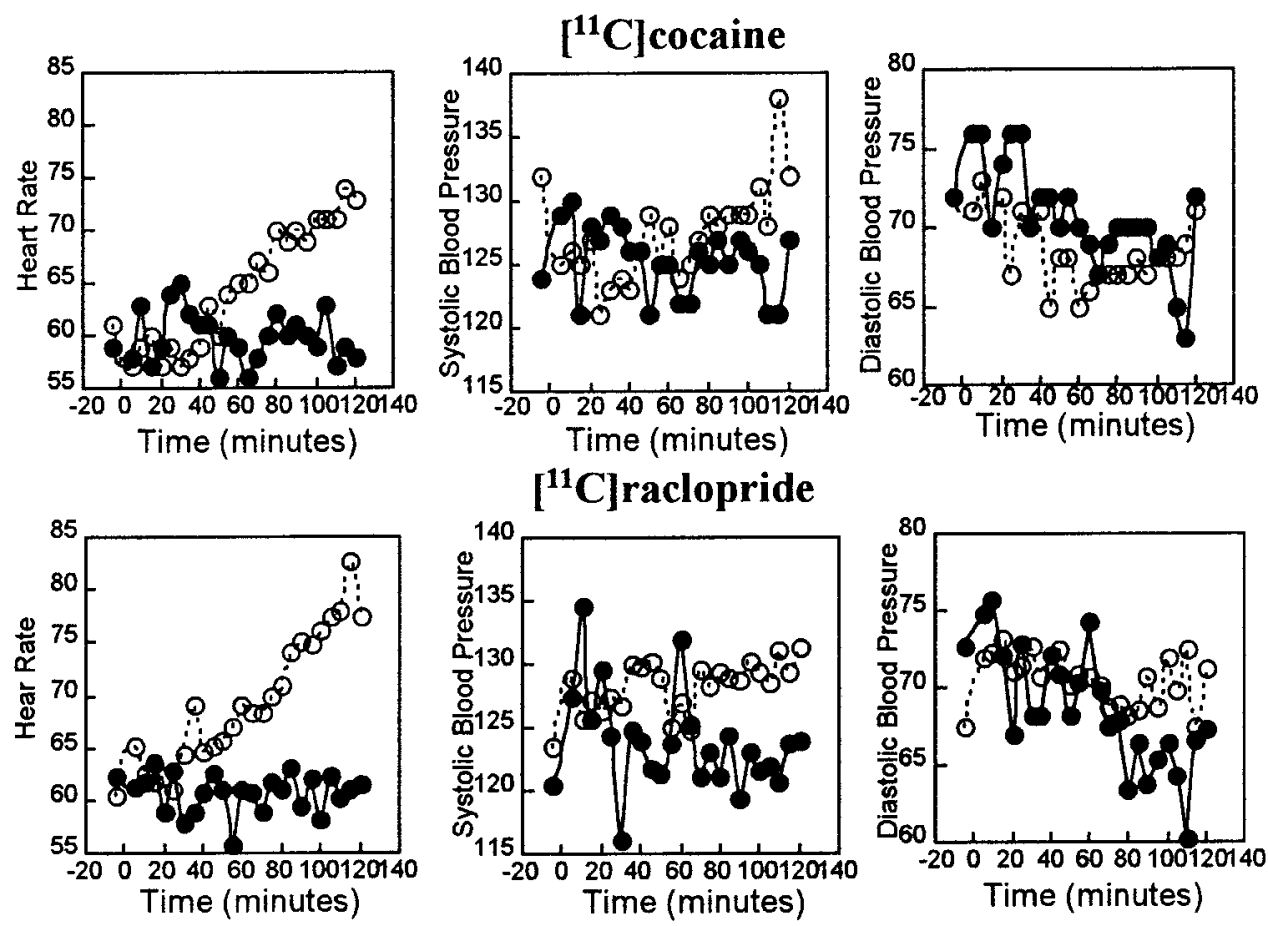

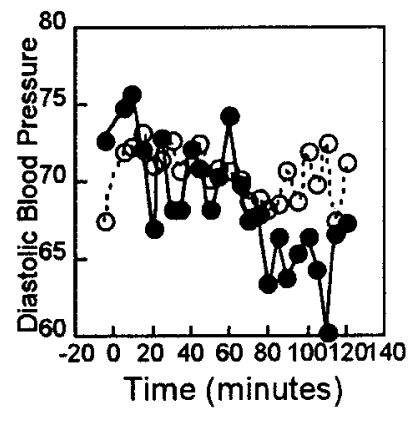

methylphenidate (active enantiomer of MP) for the $\left[{ }^{11} \mathrm{C}\right]$ cocaine and the $\left[{ }^{11} \mathrm{C}\right]$ raclopride evaluations were at $60 \mathrm{~min} 28 \mathrm{ng} / \mathrm{ml}$ and $23 \mathrm{ng} / \mathrm{ml}$, respectively. The mean plasma concentrations of d-threo-methylphenidate for the five subjects in whom we got the measures for the $\left[{ }^{11} \mathrm{C}\right]$ raclopride studies were at $60 \mathrm{~min} 30 \pm 18$ $\mathrm{ng} / \mathrm{ml}$. The levels of l-threo-methylphenidate (inactive enantiomer of MP) in these subjects were undetectable.

\section{DISCUSSION}

In this study we showed that for a fixed dose of MP the level of DAT blockade by MP was not directly related to MP-induced changes in DA. We interpret this lack of a correlation as an indication that the DA increases were due not just to DAT blockade by MP but to the individual variability in the amount of DA released by the DA cell. This interpretation is compatible with MP's pharmacological effects since MP is a DAT blocker (Kuczenski and Segal, 1997) and thus its ability to increase extracellular DA is a function both of the level of DAT blockade and of the rate of DA release. Without MP, DA that is released is rapidly removed back into the terminal, whereas when MP is given and the DAT are blocked, DA accumulates to a greater degree in the synaptic and extracellular spaces, for a given rate of release. Since the rate of DA release is mostly a function of DA cell activity (Pucak and Grace, 1994), this would imply that for an equivalent level of DAT blockade MP will induce smaller DA changes in a subject with low cell activity than in one with high DA cell activity. This is consistent with the findings that HVA levels in cerebrospinal fluid, which serve as a marker of DA turnover in CNS, predicted response to
Fig. 3. Effects of MP in heart rate and systolic and diastolic blood pressure for the $\left[{ }^{11} \mathrm{C}\right]$ cocaine and the $\left.{ }^{[11} \mathrm{C}\right]$ raclopride studies. MP significantly increased heart rate during both studies $(P<$ 0.001 ) but its effects in blood pressure were not significant. There were no differences in MP's cardiovascular effects between the two studies. 
MP in children with ADHD; the higher the levels the better the responses (Castellanos et al., 1996). Higher DA cell firing rates, which would produce higher HVA level, would result in larger increments in extracellular DA by indirect agonist MP.

This study also showed a larger intersubject variability for MP-induced increases in extracellular DA (CV $50 \%$ ) than in DAT blockade (CV 18\%). This suggests that for a fixed dose of MP the intersubject variability for MP effects is likely to be affected more by the differences in DA cell activity between subjects than by differences in DAT blockade, which primarily reflects the level of MP in plasma (Volkow et al., 1998).

The results of this study with oral doses of MP are similar to our results with intravenous doses of MP. Intravenous doses increase extracellular DA but the effects are variable across individuals; for a $0.5 \mathrm{mg} / \mathrm{kg}$ iv dose the increases ranged between $0-45 \%$ (Volkow et al., 1994). This contrasted with the relatively low intersubject variability that we had observed in a study done in a different group of subject for whom DAT blockade induced by a $0.5 \mathrm{mg} / \mathrm{kg}$ i.v. dose of MP ranged between 70-83\% (Volkow et al., 1996a). Thus, according to our revised hypothesis, individual differences in MP-induced increases to MP may reflect differences in DA tone between subjects. Since the pharmacological responses to MP will also depend on the sensitivity of DA regulated circuits, differences in sensitivity of these circuits to DA stimulation is also likely to contribute to the large intersubject variability in MP's effects (Volkow et al., 1997b).

Other factors that may contribute to individual differences in response to MP may be differences in the rate of MP's metabolism, which do result in differences in levels and duration of DAT blockade. However, this is not likely to be the main source of variability, because for a fixed dose of MP, DAT blockade is not highly variable across subjects. MP's effects on the norepinephrine transporter (Kuczenski and Segal, 1997) may also contribute to the variability.

Our revised hypothesis suggests a plausible mechanism that may underlie nonresponse to MP in some ADHD patients. It is estimated that $15-30 \%$ of children with ADHD will not respond favorably to MP (Swanson et al., 1991). Nonresponsiveness could reflect very low DA activity. Alternatively one could also speculate that "non response" when it is due to "adverse" response could occur if cell firing is extraordinarily high. However, it is likely that other mechanisms could underlie nonresponsiveness to MP, such as differences in the sensitivity or levels of DAT (Winsberg et al., 1999), differences in sensitivity of postsynaptic DA receptors and/or difference in noradrenergic activity.

In this study we assessed changes in DA induced by MP under resting conditions, but MP's therapeutic effects are made apparent when the subject performs a targeted activity (i.e., classroom work). We had previ- ously hypothesized that MP's therapeutic effects are a result of DA signal amplification (Volkow et al., 2001), which implies that MP-induced DA increases are dependent on DA cell activity. Since DA cell activity is responsive to environmental stimulation (Overton et al., 1997), this predicts that MP's effects should be context-dependent. If this hypothesis is correct, then MP-induced DA increases would be greater while performing a task that is salient to the individual, since salient stimuli activate DA cells (Schultz, 1998) than when performing a nonsalient task.

The context dependency of stimulant-induced DA increases has been demonstrated in laboratory animals for cocaine, which also increases extracellular DA by blocking DAT (Ritz et al., 1987). For example, cocaineinduced increases in DA in the nucleus accumbens are larger when animals are given cocaine in an environment where they had previously received cocaine than when they receive it in a novel environment (Duvauchelle et al., 2000) or when animals self-administer cocaine than when cocaine administration is involuntary (Hemby et al., 1997). Our current findings with oral MP point toward the need for studies of MP in subjects who are performing tasks of differing salience, to evaluate the hypothesis that MP-induced DA increases are also context-dependent.

As previously reported, both baseline DAT levels (reviewed Volkow et al., 1996b) and MP-induced changes in DA decreased with age (Volkow et al., 1994, 2001). We had previously hypothesized that the age-related decline in MP-induced DA increases reflected in part the loss of DAT with age, since these are the molecular targets for MP. However, the failure to see an association between the baseline levels of DAT and MPinduced DA changes suggests that other variables, such as a decrease in baseline DA release with age, are responsible for the age-related decline in MP-induced DA increases. Evidence of an age-associated decline in DA cell activity has been given by preclinical studies showing reductions in DA firing rate (Lavin and Drucker-Colin, 1991) and in DA release (Gerhardt and Maloney, 1999) with age.

Limitations for this study are that we were unable to get the plasma MP concentrations, which would have allowed us to control for potential differences between the two evaluations. However, this is unlikely to have affected the results since MP plasma concentrations are known to be reproducible in a given subject when tested on separate days (Shader et al., 1999). Moreover, it has been reported that both MP dose and MP plasma concentration are equally good predictors of clinical responses (Swanson et al., 1991). Although the dose used in this study is relatively high $(0.81 \pm 15 \mathrm{mg} / \mathrm{kg})$, which could account for the increased rating of "high" observed for the $\left[{ }^{11} \mathrm{C}\right]$ raclopride evaluation, the dose is still within the clinical range (Greenhill et al., 1996). Moreover, there is no reason to believe that the rela- 
tionship between DAT blockade and DA changes would be significant for a low but not for a high dose of MP. Also the $\left[{ }^{11} \mathrm{C}\right]$ raclopride competition method offers a relative estimate of DA changes, which has been shown to be linearly related to measures of extracellular DA (Breier et al., 1997), but the precise relationship between extracellular DA and $\left[{ }^{11} \mathrm{C}\right]$ raclopride changes is not known with certainty (Laruelle, 2000). Although in this study we indirectly evaluate DA tone by assessing the MP-induced changes in $\left[{ }^{11} \mathrm{C}\right]$ raclopride binding we cannot evaluate the effect of DA tone in the baseline $\left[{ }^{11} \mathrm{C}\right]$ raclopride measures. The increases in extracellular DA induced by oral MP resulted in relatively small changes in the specific binding of $\left[{ }^{11} \mathrm{C}\right]$ raclopride (average $16 \%$, range $3-27 \%$ ), which is in the range reported after intravenous administration of other psychostimulant drugs (Laruelle, 2000). These relatively small changes reflect the limited sensitivity of the $\left[{ }^{11} \mathrm{C}\right]$ raclopride displacement method; it has been estimated that an 8-fold increase in extracellular DA will decrease $\left[{ }^{11} \mathrm{C}\right]$ raclopride specific binding by less than $1 \%$ (Breier et al., 1997). Thus, we cannot rule out the possibility that in subjects in whom we did not see decreases in $\left[{ }^{11} \mathrm{C}\right]$ raclopride binding there may have been small changes in extracellular DA that were too small to be detected by the $\left[{ }^{11} \mathrm{C}\right]$ raclopride displacement method.

The lack of a correlation between the level of DAT blockade by MP and the increases in DA provides evidence that for a fixed dose of MP, the DA increases are not driven by the level of DAT blockade but most likely by the rate of DA release. Since this rate is determined by DA cell activity this suggests that differences in DA tone between subjects will affect their sensitivity to MP and that in addition MP's effects for an individual subject may be context-dependent.

\section{ACKNOWLEDGMENTS}

We thank D. Schyler for Cyclotron operations; D. Warner for PET operations; C Wong for data management; R. Ferriere, C. Shea, R. MacGregor, and P. King for radiotracer preparation and analysis; N. Pappas, N. Netusil, and P. Carter for patient care and T. Cooper for plasma methylphenidate analyses.

\section{REFERENCES}

Breier A, Su TP, Saunders R, Carson RE, Kolachana BS, de Bartolomeis A, Weinberger DR, Weisenfeld N, Malhotra AK, Eckelman WC, Pickar D. 1997. Schizophrenia is associated with elevated amphetamine-induced synaptic dopamine concentrations: evidence from a novel positron emission tomography method. Proc Natl Acad Sci USA 94:2569-2574.

Castellanos FX, Elia J, Kruesi MJ, Marsh WL, Gulotta CS, Potter WZ, Ritchie GF, Hamburger SD, Rapoport JL. 1996. Cerebrospinal fluid homovanillic acid predicts behavioral response to stimulants in 45 boys with attention deficit/hyperactivity disorder. Neuropsychopharmacology 14:125-137.

Dewey SL, Smith GS, Logan J, Brodie JD, Fowler JS, Wolf AP. 1993. Striatal binding of the PET ligand ${ }^{11} \mathrm{C}$-raclopride is altered by drugs that modify synaptic dopamine levels. Synapse 13:350-356.
Dougherty DD, Bonab AA, Spencer TJ, Rauch SL, Madras BK, Fischman AJ. 1999. Dopamine transporter density in patients with attention deficit hyperactivity disorder. Lancet 354:2132-2133.

Duvauchelle CL, Ikegami A, Asami S, Robens J, Kressin K, Castaneda E. 2000. Effects of cocaine context on NAcc dopamine and behavioral activity after repeated intravenous cocaine administration. Brain Res 862:49-58.

Efron B. 1982. The jackknife, the bootstrap, and other resampling plans. Philadelphia: SIAM.

Fowler JS, Volkow ND, Wolf AP, Dewey SL, Schlyer DJ, MacGregor R, Hitzemann R, Logan J, Bendriem B, Gatley J, Christman D. 1989. Mapping cocaine-binding sites in human and baboon brain in vivo. Synapse 4:371-377.

Gerhardt GA, Maloney RE. 1999. Microdialysis studies of basal levels and stimulus-evoked overflow of dopamine and metabolites in the striatum of young and aged Fischer 344 rats. Brain Res 816:68-77.

Gonon FG. 1988. Nonlinear relationship between impulse flow and dopamine released by rat midbrain dopaminergic neurons as studied by in vivo electrochemistry. Neuroscience 24:19-28.

Greenhill LL, Abikoff HB, Arnold E, Cantwell DP, Conners CK, Elliot G, Hechtman L, Hinshaw SP, Hoza B, Jensen PS, March J, Newcorn J, Pelham WF, Severe JB, Swanson JM, Vitiello B, Wells K. 1996. Medication treatment strategies in the MTA study: relevance to clinicians and researchers. J Am Acad Child Adolesc Psychiatry 34:1-10.

Hemby SE, Co C, Koves TR, Smith JE, Dworkin SI. 1997. Differences in extracellular dopamine concentrations in the nucleus accumbens during response-dependent and response-independent cocaine administration in the rat. Psychopharmacology (Berl) 133:7-16.

Katz JL, Izenwasser S, Terry P. 2000. Relationships among dopamine transporter affinities and cocaine-like discriminative-stimulus effects. Psychopharmacology (Berl) 148:90-98.

Kimko HC, Cross JT, Abernethy DR. 1999. Pharmacokinetics and clinical effectiveness of methylphenidate. Clin Pharmacokinet 37: 457-470.

Krause K, Dresel SH, Krause J, Kung HF, Tatsch K. 2000. Increased striatal dopamine transporter in adult patients with attention deficit hyperactivity disorder: effects of methylphenidate as measured by single photon emission computed tomography. Neurosci Lett 285:107-110.

Kuczenski R, Segal DS. 1997. Effects of methylphenidate on extracellular dopamine, serotonin, and norepinephrine: comparison with amphetamine. J Neurochem 68:2032-2037.

Laruelle M. 2000. Imaging synaptic neurotransmission with in vivo binding competition techniques: a critical review. J Cereb Blood Flow Metab 20:423-451.

Lavin MA, Drucker-Colin R. 1991. Ontogeny of the electrophysiological activity of dopaminergic cells with special reference to the influence of adrenal medullary grafts on aging. Brain Res 545:164170.

Logan J, Fowler JS, Volkow ND, Wolf AP, Dewey SL, Schlyer D, MacGregor RR, Hitzemann R, Bendriem B, Gatley SJ, Christman DR. 1990. Graphical analysis of reversible radioligand binding from time-activity measurements applied to $\left[\mathrm{N}-{ }^{11} \mathrm{C}-\right.$ methyl $]$-cocaine PET studies in human subjects. J Cereb Blood Flow Metab 10:740-747.

Logan J, Volkow ND, Fowler JS, Wang G-J, Dewey SL, MacGregor R, Schlyer D, Gatley SJ, Pappas N, King P, Hitzemann R, Vitkun S. 1994. Effects of blood flow on $\left[{ }^{11} \mathrm{C}\right]$ raclopride binding in the brain: model simulations and kinetic analysis of PET data. J Cereb Blood Flow Metab 14:995-1010.

Logan J, Volkow ND, Fowler JS, Wang GJ, Fischman MW, Foltin RW, Vitkun S, Gatley SJ, Pappas N, Hitzemann R, Shea CE. 1997. Concentration and occupancy of dopamine transporters in cocaine abusers with [11C]cocaine and PET. Synapse 27:347-356.

Overton PG, Clark D. 1997. Burst firing in midbrain dopaminergic neurons. Brain Res Brain Res Rev 25:312-334.

Pucak ML, Grace AA. 1994. Regulation of substantia nigra dopamine neurons. Crit Rev Neurobiol 9:67-89.

Ritz MC, Lamb RJ, Goldberg SR, Kuhar MJ. 1987. Cocaine receptors on dopamine transporters are related to self-administration of cocaine. Science 237:1219-1223.

Schultz W. 1998. Predictive reward signal of dopamine neurons. J Neurophysiol 80:1-27.

Shader RI, Harmatz JS, Oesterheld JR, Parmelee DX, Sallee FR, Greenblatt DJ. 1999. Population pharmacokinetics of methylphenidate in children with attention-deficit hyperactivity disorder. J Clin Pharmacol 39:775-785.

Solanto MV. 1998. Neuropsychopharmacological mechanisms of stimulant drug action in attention-deficit hyperactivity disorder: a review and integration. Behav Brain Res 94:127-152. 
Swanson JM, Cantwell D, Lerner M, McBurnett K, Hanna G. 1991. Effects of stimulant medication on learning in children with ADHD. J Learn Disabil 24:219-230.

Swanson JM, Lerner M, Williams L. 1995. More frequent diagnosis of attention deficit-hyperactivity disorder. N Engl J Med 333:944.

Swanson JM, Seargeant JA, Taylor E, Sonuga-Barke EJS, Jensen PS, Cantwell DP. 1998. Attention deficit disorder and hyperkinetic disorder. Lancet 351:429-433.

Volkow ND, Fowler JS, Wang G-J, Dewey SL, Schlyer D, MacGregor R, Logan J, Alexoff D, Shea C, Hitzemann R, Angrist B, Wolf AP. 1993. Reproducibility of repeated measures of ${ }^{11} \mathrm{C}$ raclopride binding in the human brain. J Nucl Med 34:609-613.

Volkow ND, Wang G-J, Fowler JS, Logan J, Schlyer D, Hitzemann R, Lieberman J, Angrist B, Pappas N, MacGregor R, Burr G, Cooper T, Wolf AP. 1994. Imaging endogenous dopamine competition with [11C] raclopride in the human brain. Synapse 16:255-262.

Volkow ND, Wang G-J, Fowler JS, Gatley SJ, Ding Y-S, Logan J, Dewey SL, Hitzemann R, Lieberman J. 1996a. Relationship between psychostimulant induced high and dopamine transporter occupancy. Proc Natl Acad Sci USA 93:10388-10392.

Volkow ND, Ding Y-S, Fowler JS, Wang G-J, Logan J, Gatley SJ, Hitzemann R, Smith G, Fields F, Gur R, Wolf AP. 1996b. Dopamine transporters decrease with age in healthy subjects. J Nucl Med 37:554-558.

Volkow ND, Wang GJ, Fischman MW, Foltin RW, Fowler JS, Vitkun S, Logan J, Gatley SJ, Pappas N, Hitzemann R, Shea K. 1997a. Relationship between subjective effects of cocaine and dopamine transporter occupancy. Nature 386:827-830.
Volkow ND, Wang G-J, Fowler JS, Logan J, Angrist B, Hitzemann RJ, Lieberman J, Pappas NS. 1997b. Effects of methylphenidate on regional brain glucose metabolism in humans: relationship to dopamine D2 receptors. Am J Psychiatry 154:50-55.

Volkow ND, Wang GJ, Fowler JS, Gatley SJ, Logan J, Ding YS, Hitzemann R, Pappas N. 1998. Dopamine transporter occupancies in the human brain induced by therapeutic doses of oral methylphenidate. Am J Psychiatry 155:1325-1331.

Volkow ND, Wang GJ, Fowler JS, Logan J, Gerasimov M, Maynard L, Ding YS, Gatley SJ, Gifford A, Franceschi D. 2001. Therapeutic doses of oral methylphenidate significantly increase extracellular dopamine in the human brain. J Neurosci 21:RC121.

Waldman ID, Rowe DC, Abramowitz A, Kozel ST, Mohr JH, Sherman SL, Cleveland HH, Sanders ML, Gard JM, Stever C. 1998. Association and linkage of the dopamine transporter gene and attentiondeficit hyperactivity disorder in children: heterogeneity owing to diagnostic subtype and severity. Am J Hum Genet 63:1767-1776.

Wang G-J, Volkow ND, Hitzemann RJ, Wong C, Angrist B, Burr G, Pascani K, Pappas N, Lu A, Cooper T, Lieberman JA. 1997. Behavioral and cardiovascular effects of intravenous methylphenidate in normal subjects and cocaine abusers. Eur Addict Res 3:49-54.

Wang G-J, Volkow ND, Fowler JS, Logan J, Pappas NR, Natusil N, Wong CT, Hitzemann RJ. 1999. Reproducibility of repeated measures of endogenous dopamine competition with [C-11] raclopride in the human brain. J Nucl Med 40:1285-1291.

Winsberg BG, Comings DE. 1999. Association of the dopamine transporter gene (DAT1) with poor methylphenidate response. J Am Acad Child Adolesc Psychiatry 38:1474-1477. 